\title{
Effects of exercise on cardiac autonomic modulation in children: literature update
}

\author{
Efeitos do exercício sobre a modulação autonômica \\ em crianças: atualização de literatura
}

\section{Gustavo Henrique de Oliveira Mondoni ${ }^{[a]}$, Luiz Carlos Marques Vanderlei ${ }^{[b]}$, Bruno Saraiva ${ }^{[a]}$, Franciele Marques Vanderlei ${ }^{[b] *}$}

[a] Universidade Federal de São Carlos (UFSCar), São Carlos, SP, Brazil

[b] Universidade Estadual Paulista (Unesp), Presidente Prudente, SP, Brazil

\begin{abstract}
Introduction: It is known that physical exercise is beneficial and precipitates adjustments to the autonomic nervous system. However, the effect of exercise on cardiac autonomic modulation in children, despite its importance, is poorly investigated. Objective: To bring together current information about the effects of exercise on heart rate variability in healthy and obese children. Methods: The literature update was performed through a search for articles in the following databases; PubMed, PEDro, SciELO and Lilacs, using the descriptors "exercise" and "child" in conjunction with the descriptors "autonomic nervous system", "sympathetic nervous system", "parasympathetic nervous system" and also with no descriptor, but the key word of this study, "heart rate variability", from January 2005 to December 2012. Results: After removal of items that did not fit the subject of the study, a total of 9 articles were selected, 5 with healthy and 4 with obese
\end{abstract}

\footnotetext{
* GHOM: specialist, e-mail: gustavohomondoni@gmail.com LCMV: PhD, e-mail: lcmvanderlei@fct.unesp.br BS: specialist, e-mail: bsl87@hotmail.com FMV: PhD, e-mail: franmvanderlei@gmail.com
} 
children. Conclusion: The findings suggest that exercise can act in the normalization of existing alterations in the autonomic nervous system of obese children, as well as serve as a preventative factor in healthy children, enabling healthy development of the autonomic nervous system until the child reaches adulthood.

Keywords: Physical exercise. Child. Heart rate variability. Autonomic nervous system.

\section{Resumo}

Introdução: Sabe-se que a prática de exercícios físicos é benéfica e proporciona adaptações ao sistema nervoso autônomo. No entanto, o efeito do exercício sobre a modulação autonômica cardíaca em crianças, apesar de ser uma condição importante, é pouco investigada. Objetivo: Reunir informações atuais a respeito dos efeitos do exercício físico sobre a variabilidade da frequência cardíaca de crianças saudáveis e obesas. Método: A atualização da literatura foi realizada por meio de uma busca dos artigos nas bases de dados PubMed, PEDro, Scielo e Lilacs - por meio dos descritores "exercício" e "criança" em cruzamento com os descritores "sistema nervoso autônomo", "sistema nervoso simpático", "sistema nervoso parassimpático" e também com o não descritor, mas palavra chave deste estudo, "variabilidade da frequência cardíaca" - publicados no período de janeiro de 2005 a dezembro de 2012. Resultados: Após a eliminação dos artigos que não se enquadravam no tema do artigo foi selecionado um total de nove artigos, sendo cinco com crianças saudáveis e quatro com obesas. Conclusão: Os achados sugerem que o exercício físico pode atuar na normalização das alterações existentes no sistema nervoso autonômico de crianças obesas, assim como servir como um fator de prevenção em crianças saudáveis, para que ocorra um desenvolvimento saudável do sistema nervoso autonômico até que a crianças atinja a idade adulta.

Palavras-chave: Exercício físico. Criança. Variabilidade da frequência cardíaca. Sistema nervoso autônomo.

\section{Introduction}

The influence of the autonomic nervous system (ANS) on homeostatic functions of the body has been widely studied. In the heart, the performance of the ANS depends on information from various structures, among them: baroreceptors, chemoreceptors, atrial and ventricular receptors, respiratory system modifications, the vasomotor system, the renin-angiotensinaldosterone system and the thermoregulatory system (1-3).

One of the tools that has received considerable attention in the study of autonomic action on the heart is heart rate variability (HRV), which describes the oscillations between consecutive heart beats (RR intervals) noninvasively (4-7) and has proven to be a promising measure; potentially informative for both physical and emotional health, being considered a useful prognostic index and used as a marker of morbidity and mortality (8-11).

The wide possibilities for using HRV added to the ease of data acquisition enables its use for the identification of ANS-related phenomena in individuals of different ages and states of health, as well as making evaluation possible in individuals during rest or exercise $(1,12-17)$.

Transversal cohort studies carried out in children, young people and adults using HRV for ANS assessment showed that the autonomic modulation of the sinus node changes with growth and maturation (18-20). In addition, children have lower cardiovagal baroreflex sensitivity at rest compared with adolescents and young adults, suggesting that reflex cardiovascular autonomic regulation evolves from childhood to adulthood $(18,21,22)$.

Knowledge of this change in HRV from childhood to adulthood enables alterations in the ANS to be studied in order to prevent the onset of major diseases during the development of the individual such as hypertension, diabetes, acute myocardial infarction, obesity, etc. (23-28).

It is known that, in general, high HRV is a sign of good adaptation, featuring a healthy individual with an effective ANS; on the other hand, a reduction in HRV is an indicator of abnormal and inefficient ANS adaptation (1). One method already known to cause 
significant adjustments to the functioning of the cardiovascular system and its mechanisms of autonomic adjustment is the practice of physical exercise, which has been identified as an important tool for modification of HRV, indicating that it promotes changes in autonomic modulation (29-31).

Despite existing knowledge about the benefits of physical exercise and ANS adaptations during human development, a search in the literature revealed a paucity of studies that addressed the effect of exercise on the ANS of children. This is an important condition, since the ANS controls some of the internal functions of the body and, in this sense, deserves attention.

Thus, this study aimed to bring together current information about the effects of exercise on HRV in children, in order to insert elements in the literature and contribute to a better understanding in researchers and clinicians who work in this area.

\section{Method}

This literature update was performed in May and June 2013, with articles selected from a search in the databases Medical Literature Analysis and Retrieval System Online (MEDLINE/Pubmed), Physiotherapy Evidence Database (PEDro), Scientific Electronic Library Online (SciELO) and Latin American and Caribbean Health Science Literature (Lilacs), published from January 2005 to December 2012.

To perform the search the following keywords were used, defined on the basis of Descriptors in Health Sciences (DeCS): "exercise" and "child" crossed through the Boolean operator "and" with the descriptors "autonomic nervous system", "sympathetic nervous system", "parasympathetic nervous system" and also with the non-descriptor, but keyword from this study, "heart rate variability"; in the English language the search terms used were based on Medical Subject Headings (MeSH).

All references of the selected studies were also reviewed to complement the search. All search steps were performed by only one evaluator, with the supervision of a senior reviewer.

Studies published in the last eight years, in English, Portuguese and Spanish, with children aged from seven up until 12 years, according to the Statute of Children and Adolescents (32), that analyzed the effects of physical exercise on autonomic modulation using HRV as an instrument, were included.
Cross-sectional studies and randomized and nonrandomized clinical trials available free on the internet were included. Studies published in editorial format, letters to the editor, abstracts, dissertations or academic theses were excluded in addition to studies with adolescents and adults.

After the search in the databases, the selection of articles was based on four steps. The first step was the analysis of the titles, taking into consideration the inclusion criteria of the study. The titles were required to present the main idea: analysis of the autonomic nervous system in children, through HRV, during or after exercise. The effects of all types of exercises were analyzed.

After this initial selection, the second step was initiated with a new filtering to exclude duplicate titles, since the search was conducted in more than one database. Subsequently, a detailed reading of the abstracts was performed to ensure that the articles conformed to the main ideas listed above (third step). After excluding abstracts that did not address the theme of the study, the final step was performed, characterized by reading the full articles, and selecting only those which were not excluded due to the criteria of the study.

Data were analyzed qualitatively and tabulated according to the authors and year of the study, population description, objective of the study, protocol carried out, HRV indices evaluated and conclusions found.

\section{Results}

In total, nine articles were selected, which were read in full and composed this review (Tables 1 and 2). Of the nine articles included, five related to apparently healthy children, three to obese children and one comparing eutrophic and obese children.

The sample sizes varied from 10 to 100 individuals in the studies involving only healthy children, and 29 to 103 individuals in the studies involving pathological children. In total, the studies with healthy children included 113 boys and 99 girls; only one of the articles used a control group. In the studies with pathological children, two articles did not cite the division by sex, the participants of the two remaining articles were divided into a total of 165 boys and 34 girls, of these, only one article used a placebo group for vitamin $C$ supplementation 


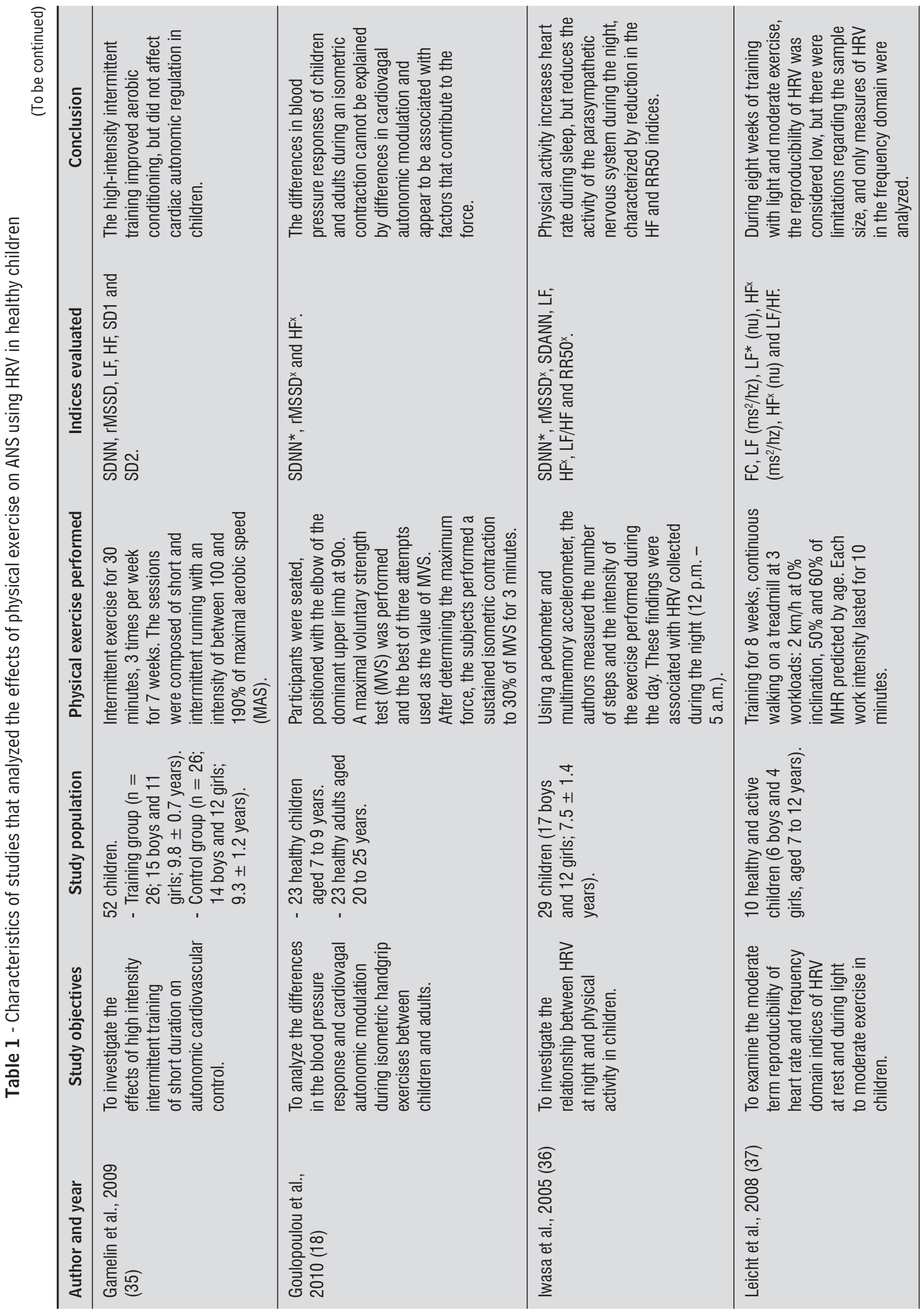




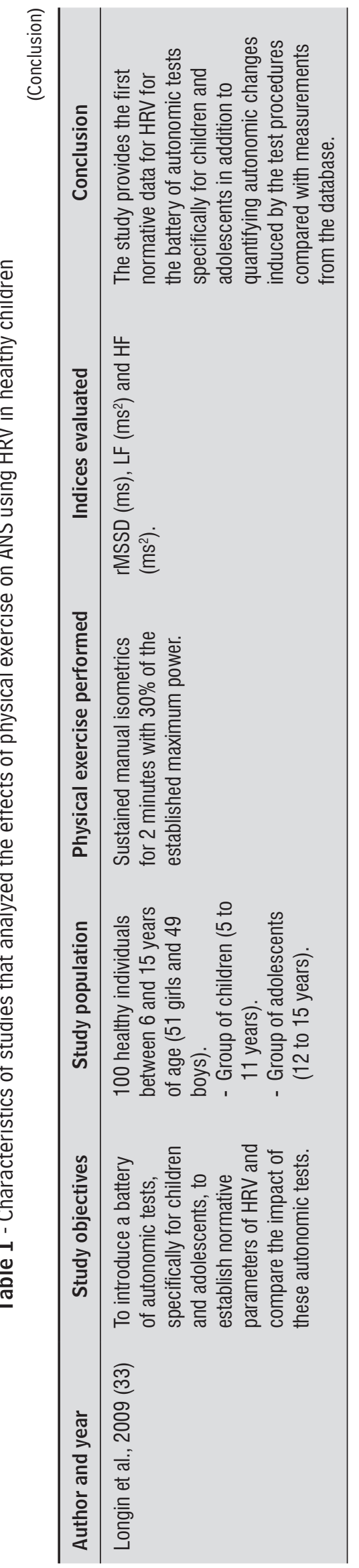

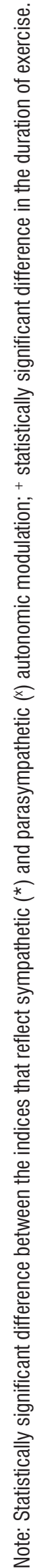

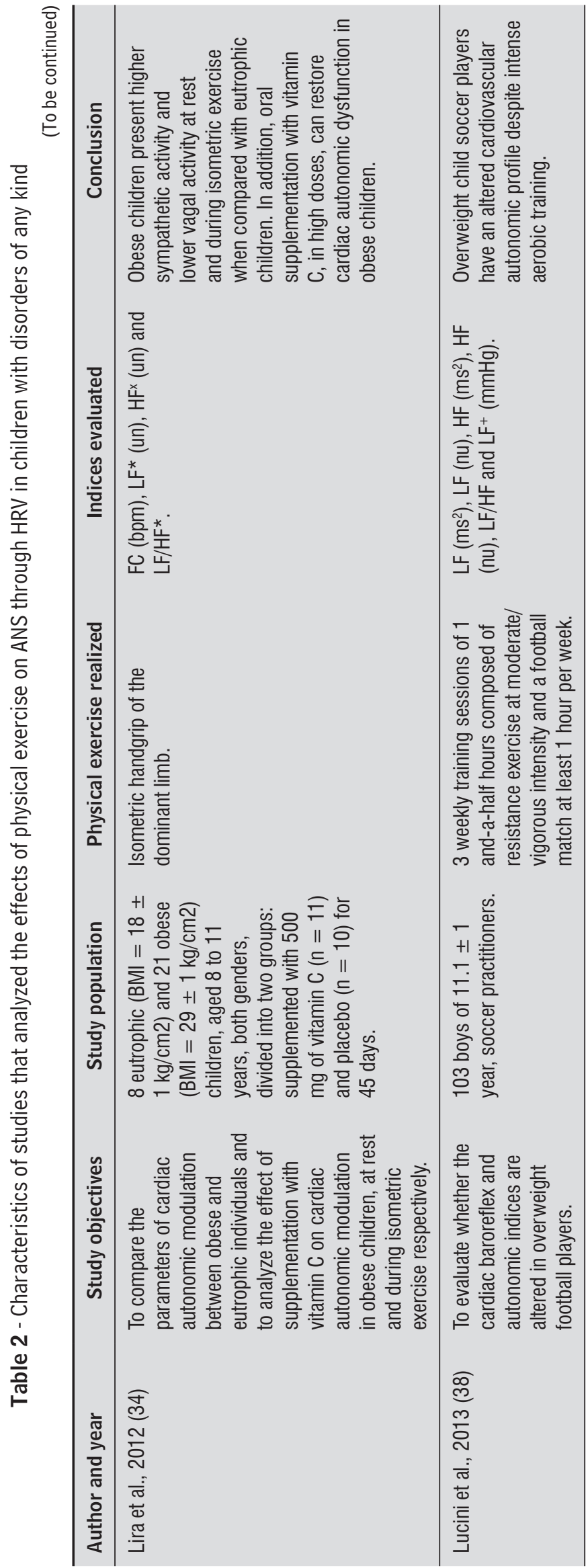




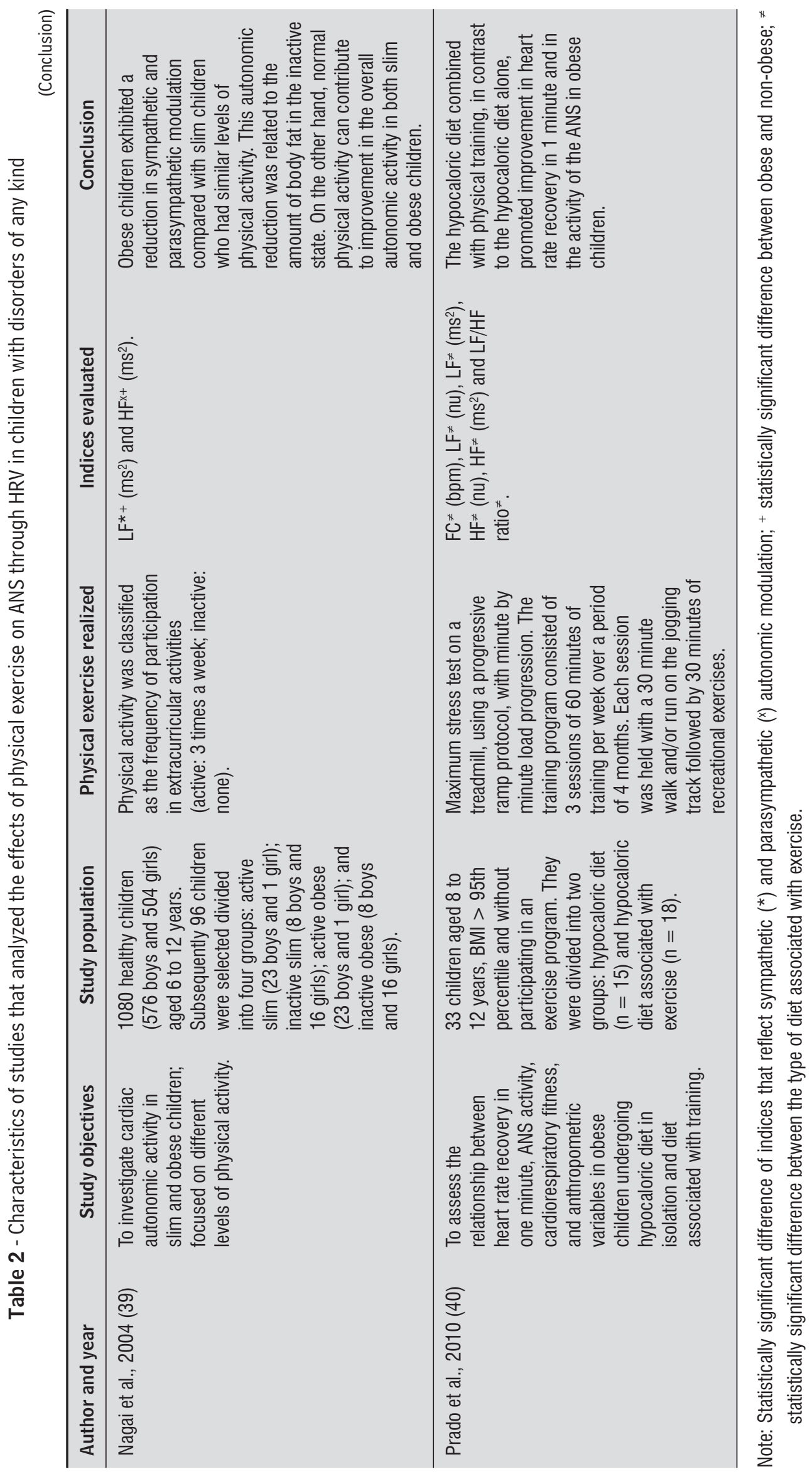


Of the articles selected with healthy children; two studied the effects of isometric contraction of the dominant limb; one studied the effects of intermittent exercise for 30 minutes; one a measurement of the number of steps and intensity of exercise performed during the day and the consequences of this on HRV during the night; and one article studied the effects of continuous walking on a treadmill over a period of eight weeks.

For the articles selected with pathological children; one article studied the effects of isometric handgrip of the dominant limb; one article studied moderate/vigorous intensity exercise three times a week; one article included a football game every week; one the frequency of participation in extracurricular activities; and one the effects of three weekly sessions of running and recreational exercises.

Among the variables studied in the selected studies, besides the HRV indices, age, sex, weight, height, calculation of body mass index (BMI), body surface area (BSA), waist circumference, body fat percentage, daily consumption of energy and fat, fat mass and obesity were also analyzed. In addition hemodynamic parameters such as heart rate (HR), systolic blood pressure (SBP), diastolic blood pressure (DBP), total peripheral resistance (TPR) and mean arterial pressure (MAP), as well as indices related to exercise such as maximal aerobic speed (VAM), $\mathrm{VO}_{2 \text { peak }}$ maximum heart rate $\left(\mathrm{HR}_{\max }\right)$ and maximal voluntary contraction (MVC) were studied.

\section{Discussion}

The analysis of the articles selected for this review showed that physical activity in apparently healthy children does not always lead to changes in cardiac autonomic modulation, regardless of whether the activity is high intensity intermittent training, isometric contraction exercises or moderate intensity exercise. It was also observed that obesity, diet and supplementation can directly affect HRV indices in children.

HRV indices were evaluated in three articles that studied the isometric contraction of the dominant upper limb. Goulopoulou et al. (18) analyzed blood pressure differences and cardiovagal autonomic modulation during isometric handgrip exercises of children and adults ( 23 healthy children aged 7 to 9 years and 23 healthy adults aged 20 to 25 years) and concluded that differences in blood pressure responses of children and adults during an isometric contraction cannot be explained by differences in cardiovagal autonomic modulation; these blood pressure differences are directly correlated with the force produced at $30 \%$ of MVC.

Another study (33) conducted a battery of autonomic tests, specifically for children and adolescents, in order to establish normative parameters of HRV and compare the impact of these autonomic tests. The authors used 100 individuals between 6 and 15 years old ( 51 girls and 49 boys) divided into two groups: a group of children aged six to 11 years and a group of adolescents aged 12 to 15 years. The study provided the first normative data for the HRV battery of autonomic tests specifically for children and adolescents, in addition to quantifying autonomic changes induced by the test procedures compared with database measurements.

Lira et al. (34) compared the indices of cardiac autonomic modulation at rest and during isometric exercise between obese and eutrophic individuals. In addition, they analyzed the effects of supplementation with vitamin $\mathrm{C}$ on cardiac autonomic modulation in obese children, at rest and during isometric exercise. According to the authors, obese children present higher sympathetic activity and lower vagal activity during rest and during isometric exercise when compared with eutrophic children. Supplementation with vitamin C, in high doses, can restore cardiac autonomic dysfunction in obese children.

The selected studies $(18,33,34)$ that evaluated autonomic modulation patterns during isometric contraction showed that obesity may be a causal factor of increased sympathetic activity and decreased vagal activity both at rest and during exercise and can be restored with supplementation of high doses of vitamin C. In apparently healthy children, it is not possible to conclude whether the blood pressure differences between children and adults are caused by differences in cardiovagal autonomic modulation.

Gamelin et al. (35) investigated the effects of high intensity intermittent training of short duration on cardiovascular autonomic control. The study population consisted of 52 children, divided into a training group ( $\mathrm{n}=26$; 15 boys and 11 girls; $9.8 \pm 0.7$ years) and a control group ( $\mathrm{n}=26 ; 14$ boys and 12 girls; 9.3 \pm 1.2 years). From this study the authors concluded that high intensity intermittent training of short duration improved aerobic conditioning, however, did not affect cardiac autonomic modulation in children.

According to some authors (36), physical activity increases heart rate during sleep, but reduces the 
activity of the parasympathetic nervous system during the night. As the HF and RR50 variables decrease with advancing age, the inhibition of the parasympathetic nervous system related to exercise, could be a development stimulus to achieve a balanced ANS pattern in adulthood.

Leicht et al. (37), examined the moderate term reproducibility of heart rate and HRV indices in the frequency domain at rest and during light to moderate exercise in ten healthy, active children (six boys and four girls aged between 7 and 12 years).The authors considered that the reproducibility of HRV was low during the eight weeks of training, but stated limitations regarding sample size and the fact that only the HRV indices in the frequency domain were analyzed.

Lucini et al. (38), evaluated whether cardiac baroreflex and autonomic indices were altered in overweight soccer players. The sample consisted of 103 male soccer players, aged $11.1 \pm 1$ year. The authors concluded that overweight child soccer players have a profile of cardiovascular autonomic changes, even though they are submitted to intense aerobic training.

Another study (39) investigated cardiac autonomic modulation in slim and obese children, focusing on different levels of physical activity. The 96 children were divided into four groups: active slim (23 boys and one girl); inactive slim (eight boys and 16 girls); active obese (23 boys and one girl); and inactive obese (eight boys and 16 girls). Physical activity was classified as the frequency of participation in extracurricular activities, whereby children were considered as active if they practiced physical activity three times a week and inactive if they did not practice any activity outside school. The authors concluded that obese children present a reduction in sympathetic, as well as parasympathetic modulation compared to slim children who have similar levels of physical activity. This reduction was related to the level of body fat in the inactive state. However, physical activity can contribute to the improvement in global autonomic modulation, both in slim and obese children.

Finally, Prado et al. (40) analyzed the relationship between heart rate recovery in one minute, ANS activity, cardiorespiratory fitness, and anthropometric variables in obese children submitted to a hypocaloric diet in isolation and associated with training. The authors evaluated 33 children aged 8 to 12 years, divided into a hypocaloric diet group and a diet associated with exercise group. The authors concluded that a hypocaloric diet combined with physical exercise, in contrast to the hypocaloric diet alone, promoted improvement in heart rate recovery in one minute and ANS activity in obese children.

In summary, the studies selected for this review showed varied responses of ANS to the performance of physical exercise in healthy children. It was possible to present the first normative HRV data for a battery of specific autonomic tests for children and adolescents. Physical activity seemed to cause an increase in heart rate during sleep and reduced activity of the parasympathetic autonomic nervous system at night. However, physical exercise was not responsible for the different blood pressure responses between children and adults, in the same way as the high-intensity intermittent training had no effect on cardiac autonomic regulation in children.

In obese children, physical exercise proved to have good potential as a tool to assist in the normalization of ANS patterns and combined with supplemental feeding and diet, may leverage these beneficial effects of training. Compared to eutrophic children, obese children had higher sympathetic activity and lower vagal activity; overweight children, even with regular practice of physical activity, presented profiles of autonomic alterations; obese children, compared with slim children with similar levels of physical activity, featured a reduction in sympathetic and parasympathetic modulation. These alterations appeared to be related to the amount of body fat.

As limitations of this review, the lack of specificity in relation to physical exercise protocols performed, the inclusion of studies with different types and intensities of effort, and the methodological differences used to assess HRV can be pointed out. The realization of stratification according to the type and intensity of exercise, in addition to verification of the effect of exercise in adolescents of different age groups and maturation stages are prospects for future studies, allowing a more enriching scenario with deeper discussion.

\section{Conclusion}

Studies have shown that physical exercise could be an important tool for the normalization of existing alterations in the ANS of obese children and may have greater power when combined with supplemented and balanced diets. In healthy children, physical exercise seems to be more a preventative factor, 
enabling healthy development of the ANS until the child reaches adulthood. Both in healthy and obese children, further studies need to be performed with larger sample sizes in order to achieve more significant results regarding the changes caused by exercise in the autonomic modulation of the ANS.

\section{References}

1. Vanderlei LCM, Pastre CM, Hoshi RA, Carvalho TD, Godoy MF. Noções básicas de variabilidade da frequência cardíaca e sua aplicabilidade clínica. Rev Bras Cir Cardiovasc. 2009;24(2):205-17.

2. Dietrich A, Rosmalen JG, Althaus M, van Roon AM, Mulder LJ, Minderaa RB, et al. Reproducibility of heart rate variability and baroreflex sensitivity measurements in children. Biol Psychol 2010;85(1):71-8.

3. Rassi Jr A. Compreendendo melhor as medidas de análise da variabilidade da frequência cardíaca: parte 2. J Diag Cardiol. 2000 [cited 2005 Feb 25];3(9). Available from: http://www.cardios.com.br/Jornais/jornal-20/metodos\%20diagnosticos.htm

4. European Society of Cardiology; North American Society of Pacing and Electrophysiology. Heart rate variability. Standards of measurement, physiological interpretation, and clinical use. Task Force of the European Society of Cardiology and the North American Society of Pacing and Electrophysiology. Eur Heart J. 1996;17(3):354-81.

5. Brunetto AF, Silva BM, Roseguini BT, Hirai DM, Guedes DP. Limiar ventilatório e variabilidade da frequência cardíaca em adolescentes. Rev Bras Med Esporte. 2005;11(1):22-7.

6. Tulppo MP, Mäkikallio TH, Seppänen T, Laukkanen RT, Huikuri HV. Vagal modulation of heart rate during exercise: effects of age and physical fitness. Am J Physiol. 1998;274(2 Pt 2):H424-9.

7. Hoshi RA, Vanderlei LCM, Pastre CM, Vanderley LC, Godoy MF. Poincaré plot indexes of heart rate variability: relationships with other nonlinear variables. Auton Neurosci. 2013;177(2):271-4.

8. Eisenberg J, Richman R. Heart rate variability during a continuous performance test in children with problems of attention. Isr J Psychiatry Relat Sci. 2011;48(1):19-24.
9. Moss D. Heart rate variability (HRV) biofeedback. Psychophysiology Today. 2004;1(1):4-11.

10. Dishman RK, Nakamura Y, Garcia ME, Thompson RW, Dunn AL, Blair SN. Heart rate variability, trait anxiety, and perceived stress among physically fit men and women. Int J Psychophysiol. 2000;37(2):121-33.

11. Godoy MF, Takakura IT, Correa PR. Relevância da análise do comportamento dinâmico não linear (Teoria do Caos) como elemento prognóstico de morbidade e mortalidade em pacientes submetidos à cirurgia de revascularização miocárdica. Arq Ciênc Saúde. 2005; 12(4):167-71.

12. Ferreira LL, Souza NM, Bernardo AFB, Vitor ALR, Vanlenti VE, Vanderlei LCM. Variabilidade da frequência cardíaca como recurso em fisioterapia: análise de periódicos nacionais. Fisioter Mov. 2013;26(1):25-36.

13. Paschoal MA, Volanti VM, Fernandes FC. Variabilidade da frequência cardíaca em diferentes faixas etárias. Rev Bras Fisioter. 2006;10(4):413-9.

14. Novais LD, Sakabe DI, Takahashi ACM, Gongora H, Taciro C, Martins LEB, et al. Avaliação da variabilidade da frequência cardíaca em repouso de homens saudáveis sedentários e de hipertensos e coronariopatas em treinamento físico. Rev Bras Fisioter. 2004;8(3):207-13.

15. Henje BE, Olsson EM, Serlachius E, Ericson M, Ingvar M. Heart rate variability is related to self-reported physical activity in a healthy adolescent population. Eur J Appl Physiol. 2009;106(6):877-83.

16. Buchheit M, Platat C, Oujaa M, Simon C. Habitual physical activity, physical fitness and heart rate variability in preadolescents. Int J Sports Med. 2007;28(3):204-10.

17. Vanderlei FM, Rossi RC, Souza NM, Sá DA, Gonçalves TM, Pastre CM, et al. Variabilidade da frequência cardíaca de adolescentes saudáveis em repouso. Rev Bras Crescimento Desenvolv Hum. 2012;22(2):173-8.

18. Goulopoulou S, Fernhall B, Kanaley JA. Developmental changes in hemodynamic responses and cardiovagal modulation during isometric handgrip exercise. Int J Pediatr. 2010;ID153780:11.

19. Pikkujamsa SM, Makikallio TH, Sourander LB, Raiha IJ, Puukka P, Skytta J, et al. Cardiac interbeat interval dynamics from childhood to senescence: comparison of conventional and new measures based on fractals and chaos theory. Circulation. 1999;100(4):393-9. 
20. Silvetti MS, Drago F, Ragonese P. Heart rate variability in healthy children and adolescents is partially related to age and gender. Int J Cardiol. 2001;81(2-3):169-74.

21. Lenard Z, Studinger P, Mersich B, Kocsis L, Kollai M. Maturation of cardiovagal autonomic function from childhood to young adult age. Circulation. 2004; 110(16):2307-12.

22. Goto M, Nagashima M, Baba R, Nagano Y, Yokota M, Nishibata $K$, et al. Analysis of heart rate variability demonstrates effects of development on vagal modulation of heart rate in healthy children. J Pediatr. 1997; 130(5):725-9.

23. Paschoal MA, Trevizan PF, Scodeler NF. Variabilidade da frequência cardíaca, lípides e capacidade física de crianças obesas e não-obesas. Arq Bras Cardiol. 2009;93(3):239-46.

24. Faulkner MS, Hathaway D, Tolley B. Cardiovascular autonomic function in healthy adolescents. Heart Lung. 2003;32(1):10-22.

25. Chen SR, Lee YJ, Chiu HW, Jeng C. Impact of physical activity on heart rate variability in children with type 1 diabetes. Childs Nerv Syst. 2008;24(6):741-7.

26. Fujii H, Fukutomi O, Inoue R, Shinoda S, Okammoto H, Teramoto T, et al. Autonomic regulation after exercise evidenced by spectral analysis of heart rate variability in asthmatic children. Ann Allergy Asthma Immunol. 2000;85(3):233-7.

27. Vanderlei LCM, Pastre CM, Freitas Junior IFF, Godoy MF. Analysis of cardiac autonomic modulation in obese and eutrophic children. Clinics. 2010;65(8):789-92.

28. Souza NM, Rossi RC, Vanderlei FM, Vitor ALR, Bernardo AFB, Gonçalves ACCR, et al. Heart rate variability in obese children. J Hum Growth Dev. 2012; 23(2):328-33.

29. Alonso DO, Forjaz CLM, Rezende LO, Braga AMFW, Barretto AC, Negrão CE, et al. Comportamento da frequência cardíaca e da sua variabilidade durante as diferentes fases do exercício físico progressivo máximo. Arq Bras Cardiol. 1998;71(6):787-92.

30. Aubert AE, Seps B, Beckers F. Heart rate variability in athletes. Sports Med. 2003;33(12):889-919.
31. Grant CC, Viljoen M, van Rensburg DC, Wood PS. Heart rate variability assessment of the effect of physical training on autonomic cardiac control. Ann Noninvasive Electrocardiol. 2012;17(3):219-29.

32. Brasil. Estatuto da criança e do adolescente. 3. ed. Brasília: Ministério da Saúde; 2008.

33. Longin E, Dimitriadis E, Shazi S, Gerstner T, Lenz T, König S. Autonomic nervous system function in infants and adolescents: impact of autonomic tests on heart rate variability. Pediatr Cardiol. 2009;30(3):311-24.

34. Lira FAS, Brasileiro-Santos MS, Borba VVL, Costa MJC, Dantas PROF, Santos AC. Influência da vitamina $C$ na modulação autonômica cardíaca no repouso e durante o exercício físico isométrico em crianças obesas. Rev Bras Saúde Matern Infant. 2012;12(3):259-67.

35. Gamelin FX, Baquet G, Berthoin S, Thevenet D, Nourry C, Nottin S, et al. Effect of high intensity intermittent training on heart rate variability in prepubescent children. Eur J Appl Physiol. 2009;105(5):731-8.

36. Iwasa Y, Kakayasu K, Nomura M, Nakaya Y, Saito K, Ito $S$. The relashionship between autonomic nervous activity and physical activity in children. Pedriatr Int. 2005;47(4):361-71.

37. Leicht AS, Allen GD. Moderate-term reproducibility of heart rate variability during rest and light to moderate exercise in children. Braz J Med Biol Res. 2008;41(7):627-33.

38. Lucini D, Giacomi G, Tosi F, Malacarne M, Respizzi S, Pagani M. Altered cardiovascular autonomic regulation in overweight children engaged in regular physical activity. Heart. 2013;99(6):376-81.

39. Nagai N, Moritani T. Effect of physical activity on autonomic nervous system function in lean and obese children. Int J Obes Relat Metab Disord. 2004;28(1):27-33.

40. Prado DM, Silva AG, Trombetta IC, Ribeiro MM, Guazzelli IC, Matos LN, et al. Exercise training associated with diet improves heart rate recovery and cardiac autonomic nervous system activity in obese children. Int J Sports Med. 2010;31(12):860-5.

Received: 09/30/2013 Recebido: 30/09/2013

Approved: 04/07/2015 Aprovado: 07/04/2015 